$$
\text { CONF- } 960912--35 \quad \text { BNL-63259 }
$$

\title{
RELATING AVIATION SERVICE DIFFICULTY REPORTS TO ACCIDENT DATA FOR SAFETY TREND PREDICTION ${ }^{a}$
}

\author{
Ralph R. Fullwood, Robert E. Hall, Gerardo Martinez-Guridi, and Stanislav Uryasev \\ Brookhaven National Laboratory, Upton NY 11973 (516) 344-2180, 2144, 7907, and 7849 (resp.) \\ and \\ S. G. Sampath \\ Federal Aviation Administration, Atlantic City NJ 08405 (609) 485-4891

\section{ar}

\section{ABSTRACT}

A synthetic model ${ }^{1}$ of scheduled-commercial U.S. aviation fatalities was constructed from linear combinations of the time-spectra of critical systems reporting using 5.5 years of Service Difficulty Reports $(\mathrm{SDR})^{2}$ and Accident Incident Data System (AIDS) records ${ }^{3}$. This model, used to predict near-future trends in aviation accidents, was tested by using the first 36 months of data to construct the synthetic model which was used to predict fatalities during the following eight months. These predictions were tested by comparison with the fatality data. A reliability block diagram (RBD) and third-order extrapolations also were used as predictive models and compared with actuality. The synthetic model was the best predictor because of its use of systems data.

Other results of the study are a database of service difficulties for major aviation systems, and arank ordering of systems according to their contribution to the synthesis.

\section{INTRODUCTION}

The U.S. Federal Aviation Administration (FAA) is responsible for the safety of 7,300 scheduled-commercial, 11,100 charters, 184,400 general aircraft. Scheduled-

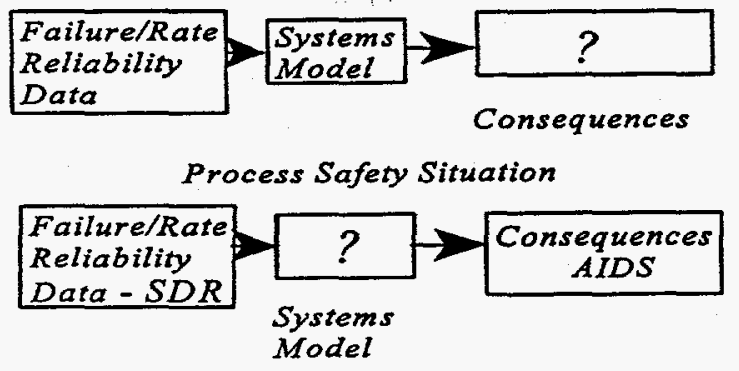

Situation for this Study

Fig. 1 Comparing Typical Process Safety with this Study Situation

\footnotetext{
${ }^{a}$ Work was done under FAA Grant 95-p-0056
}

commercial aircraft, the subject of this study, fly under the most stringent Federal Air Regulation: FAR 121. This study used two of FAA's data bases: SDRs containing service incidents related to safety, and AIDS containing accidents, fatalities and damage reports. The data encompassed January 1990 to August 1995, and consisted of 224,000 SDR records in 90 fields and 31,872 AIDS records in 181 fields.

Process industry safety studies (Figure 1) use a failure rate data base for systems and components to quantify a system model to estimate the likelihood of consequences of failure. This study had failure rate and consequence data but needed to determine a system model to connect them.

This was done by envisioning a matrix $|R|$ composed of linear combinations of service data matrices $|D|$, where the weighting coefficients are matrix IWI (Eq. 1). If IRland IDI are square, the equation can be solved to find IWI (Eq. 2). With concerns for stability, this was not done; the w's were found by leastsquares fitting of the system difficulty curves to the reference data curve (Eq. 3 ). Thus the assumption is made that service difficulties are related to the accidents and there is little time lag (phase shift).

$$
\begin{gathered}
|R|=|D| *|W| \\
|W|=\left|D^{-1}\right| *|R| \\
\sum_{t=1}^{T}\left(\sum_{n=1}^{N} w_{n} * d_{n, t}-r_{t}\right)^{2}-\min \text { of } w_{1}, \ldots w_{N}
\end{gathered}
$$

\section{REFERENCE DATA}

Figure 2 shows the structure of the reference to which the structure of selected systems is fitted.

\section{DISTRIBUTION OF THIS DOCUMENT IS UNLMITED Ph}




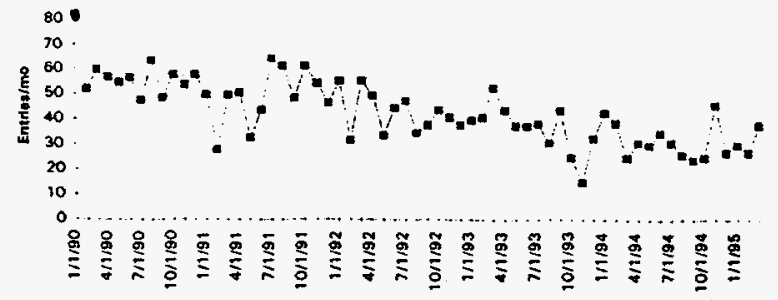

Figure 2 Reference Data

Fatalities Experienced by Carriers Flying under Part 121

\section{SYSTEMS DATA}

Figure 3 shows, for example, the data patterns for the Wing Structure system that is one of the systems fitted to the reference data.

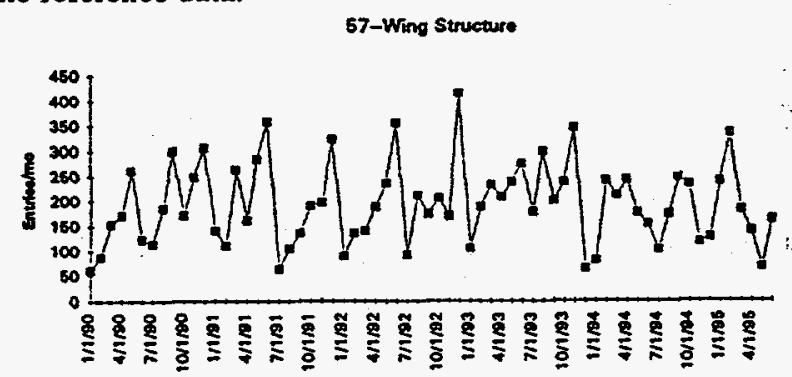

Figure 3 Example of Systems Data

\section{N. SYSTEM GROUPS}

The SDR uses the Aviation Transportation Association's (ATA) 48 major systems classifications with subsystems. For each subsystem there is a code with one digit signifying the criticality. Many systems have little direct relevance to safety and including them in the

\begin{tabular}{|l|l|l|}
\hline \multicolumn{3}{|c|}{ Table 1 Rank-Ordering Critical 45 Systems } \\
\hline No. & Description & Weight $\left(w_{n}\right)$ \\
\hline 28 & Fuel & 0.323 \\
\hline 73 & Fuel Control & 0.314 \\
\hline 76 & Mixture and Power & 0.287 \\
\hline 74 & Ignition & 0.199 \\
\hline 32 & Landing Gear & 0.194 \\
\hline 67 & Rotorcraft Flight Control & 0.104 \\
\hline 64 & Tail Rotor & 0.009 \\
\hline 63 & Main Rotor Drive & -0.018 \\
\hline 57 & Air Frame & -0.031 \\
\hline 72 & Engine & -0.084 \\
\hline 71 & Engine Cowling & -0.164 \\
\hline 65 & Tail Rotor Drive & -0.192 \\
\hline
\end{tabular}

fitting may obscure safety systems. Two types of system groups were used: subsystems having criticality rating of four or five (Table 1) and the BNL group based on engineering reasoning regarding envelope, propulsion, flight surfaces and control (Table 2).

\begin{tabular}{|l|l|l|}
\hline \multicolumn{3}{|c|}{ Table 2 Judgement-Based System Group } \\
\hline ATA No. & System Title & Reason \\
\hline 21 & $\begin{array}{l}\text { Air } \\
\text { Conditioning }\end{array}$ & $\begin{array}{l}\text { Cabin } \\
\text { pressurization }\end{array}$ \\
\hline 22 & Auto Pilot & $\begin{array}{l}\text { Navigational } \\
\text { error }\end{array}$ \\
\hline 23 & $\begin{array}{l}\text { Communi- } \\
\text { cation }\end{array}$ & $\begin{array}{l}\text { Navigational } \\
\text { error }\end{array}$ \\
\hline 24 & Electrical & Power \\
\hline 26 & Fire Protect. & Fire hazard \\
\hline 27 & Flight control & $\begin{array}{l}\text { Aircraft } \\
\text { control }\end{array}$ \\
\hline 28 & Fuel & Engine fuel \\
\hline 29 & Hydraulic & Controls \\
\hline 30 & Anti-Ice & Ice removal \\
\hline 32 & Landing Gear & Safe landing \\
\hline 34 & Navigation & Navigation \\
\hline $35,36,37$ & $\mathrm{O}_{2}$ Pneu.Vac. & Atmosphere \\
\hline $52,53,56$ & $\begin{array}{l}\text { Cabin } \\
\text { Windows }\end{array}$ & $\begin{array}{l}\text { Pressure } \\
\text { envelope }\end{array}$ \\
\hline 55,57 & $\begin{array}{l}\text { Empennage, } \\
\text { Wings }\end{array}$ & $\begin{array}{l}\text { Stabilization } \\
\text { and lift }\end{array}$ \\
\hline $72-79$ & $\begin{array}{l}\text { Eng., Fuel, Oil } \\
\text { Ignit., Cntrl, } \\
\text { Indic. Exhaust }\end{array}$ & Propulsion \\
\hline
\end{tabular}

\section{PREDICTION BASED ON SYNTHESIZED SPECTRA}

Synthetic reference (consequence) data were constructed by linearly combining system's spectra components of each of the systems groups by leastsquares linear regression fitting of the system spectra to the reference spectrum. Several fitting techniques were tried: representing both the reference spectrum and the system spectra as power-series, the reference spectrum as a power series and the system spectra as histograms, and freeform fitting with the reference and system spectra as histograms. The last one seemed to be the best because it eliminates the distortion caused by power series. The fitting coefficients are given in the right column of Table 1 for the Critical 45 systems. 


\section{DISCLAIMER}

Portions of this document may be illegible in electronic image products. Images are produced from the best available original document. 


\section{DISCLAIMER}

This report was prepared as an account of work sponsored by an agency of the United States Government. Neither the United States Government nor any agency thereof, nor any of their employees, makes any warranty, express or implied, or assumes any legal liability or responsibility for the accuracy, completeness, or usefulness of any information, apparatus, product, or process disclosed, or represents that its use would not infringe privately owned rights. Reference herein to any specific commercial product, process, or service by trade name, trademark, manufacturer, or otherwise does not necessarily constitute or imply its endorsement, recommendation, or favoring by the United States Government or any agency thereof. The views and opinions of authors expressed herein do not necessarily state or reflect those of the United States Government or any agency thereof. 
The fit using the BNL-judged systems was similar. Figure 4 compares the fitted system's spectra to the reference spectra.

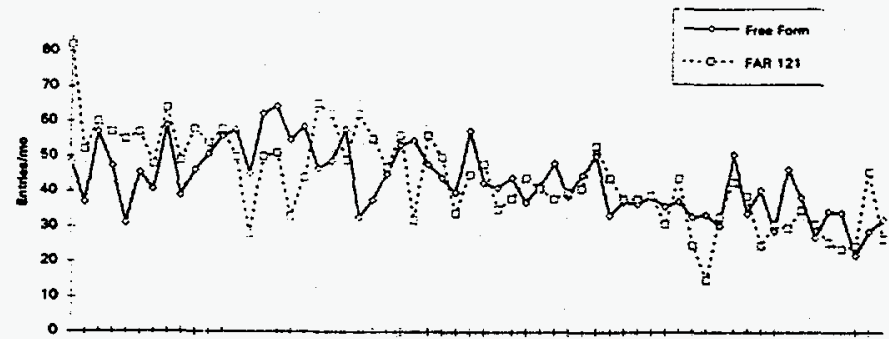

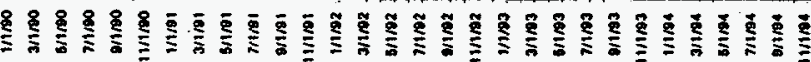
Figure 4 Comparison of Reference and Synthetic Spectra

\section{RELIABILITY MODEL-BASED PREDICTION}

\section{A. Entry Data}

The SDR data base was searched to compile the number of system entries for aircraft flying under FAR 121. The results are presented in Table 3 in terms of ATA system designation, description and entries per flight. These results may be converted to entries/flight hours by multiplying by 0.645 or entries per year by multiplying by $8 . e+6$.

\begin{tabular}{|l|l|l|}
\hline \multicolumn{3}{|c|}{ Table 3 Incident Data } \\
\hline $\begin{array}{l}\text { ATA } \\
\text { No. }\end{array}$ & Description & $\begin{array}{l}\text { Entries } / \\
\text { flight }\end{array}$ \\
\hline 1200 & Servicing & $1.24 \mathrm{e}-05$ \\
\hline 1800 & Helicopter Vibration & $0.00 \mathrm{e}+00$ \\
\hline 2100 & Air-conditioning & $8.04 \mathrm{e}-05$ \\
\hline 2200 & Auto pilot & $5.29 \mathrm{e}-06$ \\
\hline 2300 & Communications System & $1.16 \mathrm{e}-05$ \\
\hline 2400 & Electrical Power System & $5.63 \mathrm{e}-05$ \\
\hline 2500 & Interior Equipment & $5.72 \mathrm{e}-05$ \\
\hline 2600 & Fire Protection & $7.18 \mathrm{e}-05$ \\
\hline 2700 & Flight Control System & $1.31 \mathrm{e}-04$ \\
\hline 2800 & Fuel System & $1.97 \mathrm{e}-05$ \\
\hline 2900 & Hydraulic System & $5.72 \mathrm{e}-05$ \\
\hline 3000 & Anti-ice System & $2.30 \mathrm{e}-05$ \\
\hline 3100 & Instruments & $1.22 \mathrm{e}-05$ \\
\hline 3200 & Landing Gear & $4.16 \mathrm{e}-04$ \\
\hline 3300 & Lighting System & $4.31 \mathrm{e}-04$ \\
\hline 3400 & Navigation System & $6.51 \mathrm{e}-05$ \\
\hline 3500 & Oxygen System & $1.64 \mathrm{e}-05$ \\
\hline 3600 & Pneumatic System & $2.44 \mathrm{e}-05$ \\
\hline
\end{tabular}

\begin{tabular}{|l|l|l|}
\hline 3700 & Vacuum System & $3.88 \mathrm{e}-07$ \\
\hline 3800 & Water and Waste System & $2.39 \mathrm{e}-06$ \\
\hline 4500 & Central Maintenance Computer & $0.00 \mathrm{e}+00$ \\
\hline 4900 & Airborne APU System & $1.51 \mathrm{e}-05$ \\
\hline 5100 & Practices/structures Balloons & $0.00 \mathrm{e}+00$ \\
\hline 5200 & Doors & $1.51 \mathrm{e}-04$ \\
\hline 5300 & Fuselage & $1.20 \mathrm{e}-03$ \\
\hline 5400 & Nacelles/pylons Structure & $4.45 \mathrm{e}-05$ \\
\hline 5500 & Empennage Structure & $7.56 \mathrm{e}-05$ \\
\hline 5600 & Windows Windshield System & $1.50 \mathrm{e}-05$ \\
\hline 5700 & Wing Structure & $2.96 \mathrm{e}-04$ \\
\hline 6100 & Propeller System & $4.99 \mathrm{e}-05$ \\
\hline 6200 & Main Rotor System & $1.25 \mathrm{e}-06$ \\
\hline 6300 & Main Rotor Drive & $1.03 \mathrm{e}-06$ \\
\hline 6400 & Tail Rotor & $9.57 \mathrm{e}-07$ \\
\hline 6500 & Tail Rotor Drive System & $9.12 \mathrm{e}-08$ \\
\hline 6700 & Rotorcraft flight control & $5.47 \mathrm{e}-07$ \\
\hline 7100 & Power Plant & $2.71 \mathrm{e}-05$ \\
\hline 7200 & Engine (Turbine/turboprop) & $1.15 \mathrm{e}-04$ \\
\hline 7300 & Engine Fuel and Control & $5.50 \mathrm{e}-05$ \\
\hline 7400 & Ignition System & $2.48 \mathrm{e}-06$ \\
\hline 7500 & Engine Bleed Air System & $1.45 \mathrm{e}-05$ \\
\hline 7600 & Engine Controls & $1.11 \mathrm{e}-05$ \\
\hline 7700 & Engine Indicating System & $3.43 \mathrm{e}-05$ \\
\hline 7800 & Engine Exhaust & $1.31 \mathrm{e}-05$ \\
\hline 7900 & Engine Oil System & $2.50 \mathrm{e}-05$ \\
\hline 8600 & Engine Starting & $4.40 \mathrm{e}-06$ \\
\hline 8100 & Turbine System (Recip. Only) & $1.82 \mathrm{e}-07$ \\
\hline 8200 & Water Injection & $7.98 \mathrm{e}-07$ \\
\hline 8300 & Accessory Gearboxes & $5.47 \mathrm{e}-07$ \\
\hline 8500 & Engine Reciprocating & $7.16 \mathrm{e}-06$ \\
\hline & & \\
\hline
\end{tabular}

\section{B. Reliability Block Diagram}

For more conventional system modeling, the reliability block diagram shown in Figure 5 was used using the systems group from Table 2. This diagram indicates that each of these 19 systems must function properly for successful operation. The failure rate of this aircraft model is found by using the failure rates of each system from Table 3 as summarized in Table 4. The result (corresponding to logical "OR"ing) of the system failure rates is a frequency of $2.76 \mathrm{E}-3 /$ flight. 
The AIDS data shows 2851 total (passengers, crew and ancillaries) fatalities over a 5.5 year period which is equivalent to $6.5 \mathrm{E}-5$ fatalities/flight ${ }^{4}$. The ratio of the entry rate/flight to the fatality rate/flight is 42.5 .

\section{ANALYTIC CONTINUATION-BASED PREDICTION}

Fitting the reference spectrum to a power series in time may also be used to predict future trends by specifying time into the future from the time of the fitting. Figure 6 compares the reference spectrum to the fit based on the equation: fatalities/month $=61.9-0.778 \mathrm{t}+$ $0.0082 t^{2}-0.00008 t^{3}$ where $t$ is the number of months after January 1990.

\begin{tabular}{|l|l|l|}
\hline \multicolumn{3}{|c|}{ Table 4 Failure Evaluation } \\
\hline $\begin{array}{l}\text { ATA } \\
\text { No. }\end{array}$ & Title & $\begin{array}{l}\text { Entry } \ldots \ldots . . . \\
\text { Rate/flight }\end{array}$ \\
\hline 21 & Air-conditioning & $8.04 \mathrm{e}-5$ \\
\hline 22 & Auto Pilot & $5.29 \mathrm{e}-6$ \\
\hline 23 & Communications & $1.15 \mathrm{e}-5$ \\
\hline 24 & Electrical & $5.63 \mathrm{e}-5$ \\
\hline 26 & Fire Protect. & $7.18 \mathrm{e}-5$ \\
\hline 27 & Flight control & $1.31 \mathrm{e}-4$ \\
\hline 28 & Fuel & $1.97 \mathrm{e}-5$ \\
\hline 29 & Hydraulic & $5.72 \mathrm{e}-5$ \\
\hline 30 & Anti-Ice & $2.3 \mathrm{e}-5$ \\
\hline 32 & Landing Gear & $4.16 \mathrm{e}-5$ \\
\hline 34 & Navigation & $6.51 \mathrm{e}-5$ \\
\hline 35, & Oxygen, Pneumatic, & $4.55 \mathrm{e}-5$ \\
36,37 & Vacuum & \\
\hline 52,53, & Fuselages, Doors, & $1.35 \mathrm{e}-3$ \\
56 & Windows & \\
\hline 55,57 & Empennage, Wings & $5.07 \mathrm{e}-4$ \\
\hline $72-79$ & $\begin{array}{l}\text { Engine, Fuel, Ignition, } \\
\text { Bleed, Controls, }\end{array}$ & $2.98 \mathrm{e}-4$ \\
& Indicating, Exhaust, \\
Oil & Total & $2.76 \mathrm{e}-03$ \\
\hline
\end{tabular}

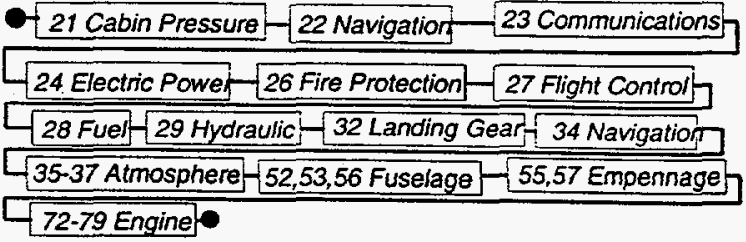

Figure 5 Reliability Block Diagram

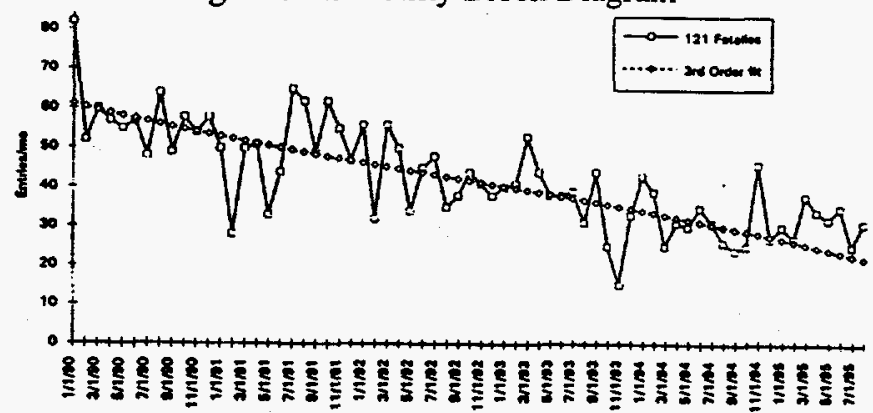

Figure 6 Third-Order Fit and Reference Data

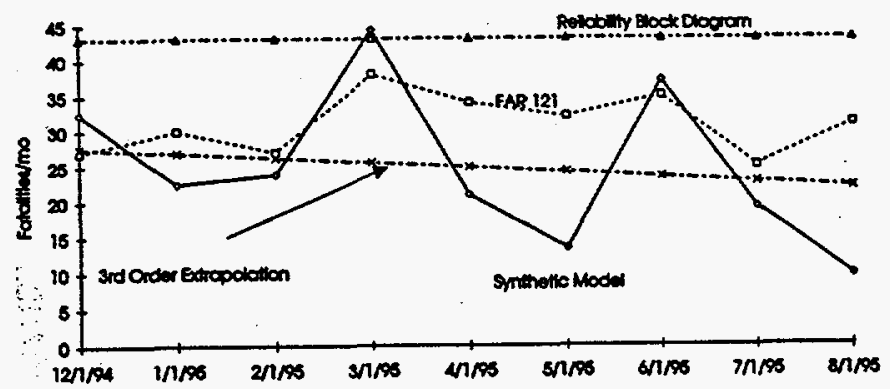

Figure 7 Prediction Test

FAR121, Synthetic Model, RBD, and 3rd Order Fit

\section{TEST OF PREDICTIONS}

Figure 7 uses data previous to December 1994 to predict the fatalities from December 1994 to August 1995. The RBD prediction is high because it is based on data averaged over 5.5 years; the third-order fit continues the downward trend of the data while there is a suggestion that there are increasing fatality rates from February 1995 to the end of data. The synthetic model, based on SDR inspection data seems to show this increasing tendency.

\section{TEST OF ROBUSTNESS}

The synthetic model uses data in one time region to construct a model from the SDR data to predict the fatality rate in future time. The stability of this model to the time region of fitting was tested. Figure 9 shows the prediction of the synthetic model for different fitting times: first 5.5 years, first 2.5 years and second 2.5 years. The results are remarkably independent of the 
fitting time for this data.

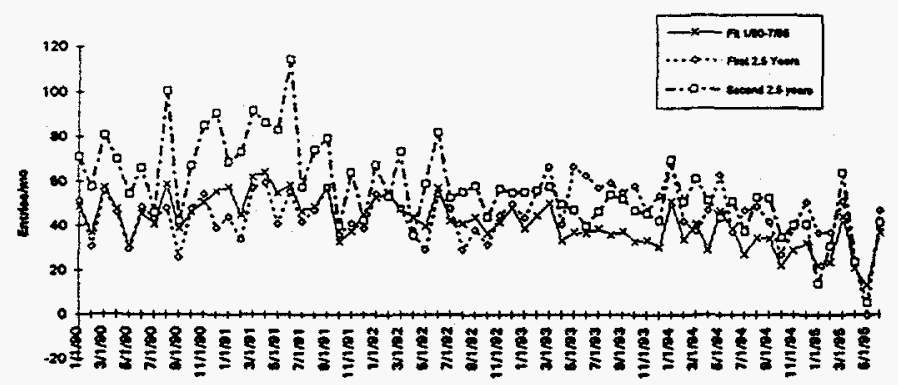

Figure 8 Test of Synthetic Model Stability

\section{CONCLUSIONS}

The spectra of critical system difficulties have been numerically related to the spectrum of fatalities for scheduled, commercial air carriers to construct a synthetic model to predict near-future aviation experience. Tests show that the synthetic model is a better predictor than the reliability block diagram model or by analytic continuation of a power series in time fit to data.

In the course of this work, the entry frequency for the 48 ATA system classifications was prepared and presented. Work not reported here determined the linear regression slope and intercept as well as a correlation coefficient with the reference data.

Table 1 provides the amplitudes of the system spectra which are used to rank-order the systems according to their importance to the fit. The negative coefficients caused by rotorcraft data confuse the interpretation. However, it should be noted that they are of low amplitude. Future work may entail separation of fixedwing and rotor craft.

\section{REFERENCES}

1. Fullwood, et al., "Relating Aviation Service Difficulty Reports to Accident Data for Safety Trend Prediction," BNL Tech. Rpt. 63018, March 1996.

2. DOT, FAA, "Flight Standards Service Difficulty Program," Order 8010.2, Feb. 22, 1978, reissued 4:5/14/81.

3. DOT/FAA, "Aviation Standards Accident/Incident Data System - AIDS," Users Guide VS ASAS-D-335, July 1982.

4. National Transportation Safety Board, "Annual
Review of Aircraft Accident Data U.S. Air Carrier Operations Calendar Year 1993," PB95-261723 NTSB/ARC-95/01. 